\title{
Do high performance work systems enhance business performance? Examining the mediating influence of total quality management*
}

\author{
Emilio Ruiz ${ }^{1}$, Jesús David Sánchez de Pablo ${ }^{2}$, Rosa M. Muñoz ${ }^{3}$, \\ Isidro Peña ${ }^{4}$
}

\begin{abstract}
This paper analyses the effect of High-Performance Work Systems (HPWS) and Total Quality Management (TQM) on business performance. An extensive literature review made it possible to establish four hypotheses, along with a comprehensive path model of relationships tested by means of structural equation modelling (SEM) using the partial least squares (PLS) technique. The results show that HPWS positively influence business performance and TQM which, in return, directly improves business performance and mediates in the HPWS-business performance relationship. Upon considering these conclusions, we can, therefore, state that the integration of both human resource management and total quality management is a key strategy for a company.
\end{abstract}

Key words: high performance work systems, total quality management, mediation, business performance, partial least square

JEL classification: M50

* Received: 13-07-2018; accepted: 17-05-2019

${ }^{1}$ PhD of University of Castilla-La Mancha, Faculty of Law of Social Sciences, Ronda de Toledo s/n, 13071 Ciudad Real. Scientific affiliation: human resource strategic management, total quality management and partial least square, Spain. Phone: +34 926295300. Fax: +34 926295407.E-mail: emilio.ruiz@alu.uclm.es.

2 Assistant Professor, University of Castilla-La Mancha, Faculty of Law of Social Sciences, Ronda de Toledo s/n, 13071 Ciudad Real, Spain. Scientific affiliation: strategic alliances, innovation, knowledge management and human resource strategic management. Phone: +34926295300 Ext. 3429. Fax: +34 926295407.E-mail: jesusdavid.sanchez@uclm.es (corresponding autor).

${ }^{3}$ Full Professor, University of Castilla-La Mancha, Faculty of Law of Social Sciences, Ronda de Toledo s/n, 13071 Ciudad Real, Scientific affiliation: human resource strategic management, entrepreneurship and corporate social responsibility. Phone: +34 926295300 Ext. 3594. Fax: +34926295407.E-mail: rosamaria.munoz@uclm.es.

4 Assistant Professor, University of Castilla-La Mancha, Faculty of Law of Social Sciences, Ronda de Toledo s/n, 13071 Ciudad Real, Scientific affiliation: strategic alliances, innovation, knowledge management and human resource strategic management. Phone: +34 926295300 Ext.3531.Fax: +34 926295407.E-mail: isidro.pena@uclm.es. 


\section{Introduction}

Strategic human resource management (SHRM) has focused on examining the performance effects associated with a set of human resource practices designated as high-performance work systems (HPWS). Much of this SHRM research has examined the impact of a bundle or system of human resource practices on organisational outcomes (Huselid, 1995; Delery and Doty, 1996; Guthrie, 2001; Batt, 2002). Although there is increasing research into HPWS and its effects on performance, many questions regarding this field remain unanswered: a) the exact specification of the set of human resource practices comprising a high performance work system; b) which performance measures are most suitable, and c) the nature of the impact of HPWS on organisational outcomes, that is, the processes by which these human resource practices affect a firm's performance (Guthrie, Flood, Liu andMacCurtain, 2009; Takeuchi, Chen and Lepak, 2009; Zhang,Zhu, Dowling and Bartram, 2013; Peña, Sánchez de Pablo, Hernández and Villasalero, 2015). This has resulted in the addition of new variables which show a mediator effect between human resource management and organisational performance. In this respect, Guest (1997) state that it is essential to discover the mediating relationship existing among the HPWS and a firm's performance. In this research, we have considered Total Quality Management (TQM) as the key variable in the human resourcesperformance relationship (Alfalla, Marín and Medina, 2012). The main reason for this choice is that many researchers have focused on analysing the value of TQM as regards improving performance, suggesting that its implementation is positively associated with a firm's operational performance in terms of cost, flexibility and quality (Powell, 1995; Easton and Jarrell, 1998; Samson and Terziovski, 1999; Taylor and Wright 2003). That is, TQM plays an important role in the final results achieved by the firm. There is also mounting interest in both the theory and practice regarding the relationship between human resource management and TQM and its effect on a company's results (Boon, Arumugam, Samaun and Abu, 2007).

The objectives of this work can, therefore, be resumed as follows: a) to verify the effects of HPWS upon business results and b) to analyse the mediating effect of TQM between both variables. That is, the research question we wish to address is whether the implementation of HPWS directly affects the obtaining of better company results or whether it does so owing to the existence of TQM practices (mediation effect).

The gap in literature that we wish to cover is, therefore, the fact that numerous studies measuring the continuous effect of a set of human resources practices on business results exist, but few also consider the mediating effect of quality practices. If we are successful in showing this effect, then companies should include TQM in the management process and fit the high-performance work practices to the TQM strategy. 
This work is structured as follows: we shall first present the ideas and contributions of various authors, which will serve to develop the model, the research hypotheses, and to describe the variables; we shall then go on to present the sample used in the methodological aspects, and we shall describe the manner in which the information was obtained and the measurement of the variables; we shall then carry out the empirical analysis through the use of the structural equation modelling (SEM) technique and, finally, we shall present the main results and conclusions of this research.

\section{Literature review}

In this section, we provide a review of the literature on theories of HPWS, of TQM and of the link between HPWS/TQM and business performance.

\subsection{High Performance Work Systems}

Pfeffer $(1994,1998)$ has argued that success in marketplace is largely the result of a firm's human resources (HR). This idea represents the view of a growing number of scholars in the field of management (Lin, 1998; Vinten, 2000; Warren and Hutchinson, 2000).

A wide range of approaches that can be employed to analyse human resource practices are currently available. There are authors who, within a universalistic approach, state that some staff management practices are better than others (Delaney and Huselid, 1996). These researchers posit that some human resource practices are always better than others and that all organisations should adopt these best practices. For instance, Pfeffer (1994) considers 16 management practices, such as incentive pay, participation and empowerment, promotion from within, employment security or training, a greater use of which results in higher productivity and profit across organisations.

We can, however, also find supporters of the contingent perspective who state that the human resource policies along with their objectives will clearly depend on the strategic orientation followed by the firm (Miles and Snow, 1978; Schuler and Jackson, 1987).

Finally, other authors have ascribed to the configurational approach, and consider that human resource practices must be seen as a system (Wright and Snell, 1991) in order to achieve synergies that can improve results.

Although these discrepancies regarding the approach to the study of human resource management could lead us to believe that the literature on this topic is a senseless theory, according to Delery and Doty (1993), all three points of view are 
viable, each of them leading to different assumptions about the relationships that exist between human resource practices and organisational results.

Configurational theories differ from universalistic and contingency theories because the former are guided by the holistic principle of inquiry, are usually based on typologies of ideal types, and explicitly adopt the systems assumption of "equifinality" (Doty and Glick, 1994). In this respect, therefore, configurational arguments are more complex than those of either of the previous two theoretical perspectives. Configurational ideas are incorporated into empirical strategic human resource management studies when researchers attempt to identify configurations of human resource practices that predict superior performance when used in associations with each other, or the correct strategy, or both (Delery and Doty, 1996). Ichniowski, Shawand Prennushi (1997) state that combinations of human resource management practices have greater effects on productivity than the sum of the component effects owing to individual practices. This is clearly an argument in support of a configurational perspective.

If we consider another point of view, the resource-based view of the firm (Grant, 1996) posits that companies can develop sustained competitive advantage only by creating value in a way that is rare and difficult for competitors to imitate. Resources such as technology, natural resources, economies of scale and so forth are increasingly easy to imitate, especially in comparison to a complex social structure such as an employment system. In this respect, human resource strategies may be an especially important means of achieving sustained competitive advantage (Pfeffer, 1994; Riaz, 2016). The concept of the human resources system as a strategic asset has implications for both the characteristics and the effects of such a system. A properly developed human resources system is an invisible asset that creates value when it is so embedded in the operational systems of a firm that it enhances the company's capabilities. With its implicit systems perspective, the resource-based view of the firm suggests the importance of "complementary resources", the notion that individual practices have a limited ability to generate competitive advantage in isolation but can, in combination, enable a company to realise its full competitive advantage. That is, a system of human resource practices may be more than the sum of the parts, which is connected with concepts such as synergy, bundles, holistic approaches, configurations, and so forth (Huselid, 1995).

In relation to the configurational approach and the resource-based view of the firm, we present the concept of HPWS. This refers to "an internally consistent set of policies and practices that ensure that a firm's human capital (employees' collective knowledge, skills, and abilities) contributes to the achievement of business objectives" (Huselid, Jackson and Schuler1997). The specific effective human resource management practices that enhance a firm's performance are: extensive recruitment, selection, and training procedures, job design, attitude assessment, formal information sharing, labour-management participation programmes, 
promotion and incentive compensation systems with which to recognise employee merit (Huselid, 1995; Pfeffer, 1998; Guthrie, 2001; Datta, Guthrie and Wright, 2005; Zhang and Morris, 2014).

\subsection{Total Quality Management}

There are many definitions of TQM. It is an integrated management philosophy and a set of practices that emphasises, among other things, meeting customers' requirements, continuous improvement, process redesign, competitive benchmarking, team-based problem-solving, closer relationships with suppliers and the constant measurement of results (Yang, 2005).

According to many researchers, TQM does produce value through a variety of benefits (Lee and Lee, 2015; Valmohammadi and Roshanzamir, 2015). It is possible to achieve: an improved understanding of customers' needs; improved customer satisfaction; better problema-solving, improved internal communication; stronger relationships with suppliers; reduced waste, greater employee commitment and motivation, and fewer errors. A resource-based analysis supports this conclusion, suggesting that TQM is not readily imitable owing to time compression diseconomies, causal ambiguity, connectedness of resources, and social complexity. The success of TQM depends not only on adopting the TQM attributes, but also on complementary factors that are apparently unrelated to TQM, yet more difficult to imitate than TQM itself. It appears to require a culture which is receptive to change, leadership qualities, and a motivation to improve. Without these tacit, intangible and difficult to imitate complementary resources, TQM programmes have no foundation for success (Powel, 1995; Anderson and Sohal, 1999; Samson and Terziovski, 1999; Aquilani, Silvestri, Ruggieri, and Gatti, 2017; Bouranta, Psomas and Pantouvakis, 2017).

At the core of TQM's ability to create value is its power to bring about an efficient creation and utilisation of valuable specific knowledge at all levels of the organisation. This contribution to knowledge creation brings about improvements in some distinctive competencies, such as managerial competencies, employee knowhow, external cooperation skills, the creation of a collective mind, organisational commitment, stimulation of the organisational learning process, speed and flexibility in the design of new products or services and reputation (Lemak and Reed, 1997; Wruck and Jensen, 1998; Escrig, Bou and Roca, 2001).

In order to analyse whether TQM acts as a mediating variable in the relationship between HPWS and the generation of improved business performance (BP), we propose the model shown in Figure 1. Four hypotheses were derived from this model.

Research indicates that the choice of HR systems can have an economically significant effect on a firm's performance. Reasonable changes in an HR system 
can increase a firm's market value, can affect the probability of survival for a new firm, and can have significant effects on intermediate outcomes (productivity, profit, product quality, sales, customer satisfaction, employee motivation, decreased employee absenteeism and turnover) that are consistent with an ultimate bottom line effect. In summary, at multiple levels of analysis there is consistent empirical support for the hypothesis that human resources can make a meaningful difference to a company's bottom line (Ichniowskiet al., 1997; Wood, 1999; Batt, 2002; Datta et al., 2005; Takeuchi, Lepak, Wang, and Takeuchi, 2007). Huselid (1995) states that "across a wide range of industries and firm sizes, I found considerable support for the hypothesis that investments in such practices are associated with lower employee turnover and greater productivity and corporate financial performance".

In this research, the above lines of reasoning will be employed to test the first hypothesis: HPWS have a positive significant effect on the performance of the organisation.

Human resource participation in TQM practices is not optional, but is rather an essential component if quality management is to reach its full potential (Soltani, Gennard, Van der Meer and Williams, 2004; Boon et al. 2007). In fact, the evidence suggests that lack of success, rather than being owing to any inherent flaw in the TQM concept itself, arises partly form the lack of congruence between TQM requirements and human resource management (Kochan, Gittell, and Lautsch, 1995; Yang, 2006). Furthermore, to add to the importance of HRM in the successful implementation of quality management programmes, some authors believe that the type of leadership and the HRM system adopted by the company can significantly determine TQM (Powell, 1995; Samson and Terziovski, 1999).

Human resource policies and practices have an important role to play in facilitating the implementation of TQM. No matter how sophisticated the quality strategy of the organisation is, it will not pass with excellence unless people are earnestly concerned about and committed to it. Both HRM and TQM focus on creating sustained competitive advantage through HPWS that include practices such as employee participation, leadership, empowerment, teamwork, job rotation, employee development and pay for performance. Both HRM and TQM underline the existence of HPWS that drive organisations towards excellent performance (Jiménez and Martínez, 2009; Abu-Doleh, 2012; Izvercian, Radu, Ivascu and Ardelean, 2014).

The synergy and congruence among HRM practices, therefore, have significant effects on the implementation of TQM. With regard to the linkage between HRM practices and TQM practices, the results are that TQM generates improved quality products and services, raises production performance, and reduces cost, thus improving business competitiveness (Yang, 2006; Abu-Doleh, 2012; Alfalla et al, 2012). 
The most commonly employed techniques as regards providing quality leadership and determining the effectiveness of TQM are the quality awards criteria. Many companies choose this means of achieving competitive advantage, e.g. ISO 9000, EFQM, and awards such as "Malcolm Baldrige" or "Deming Prize". These organisations should improve HR practices such as training, employee participation, performance appraisal, and empowerment because it is the best established and recongnised framework for quality improvement (Vouzas, 2007; Izvercian et al. 2014).

The above lines of reasoning will be used as a basis to test the second hypothesis: HPWS have a positive significant effect on the TQM.

TQM principles and techniques came into being more than two decades ago and are now a well-accepted part of almost every manager's activities. The quality precepts and concepts have been summarised and characterised by a number of researchers (Ahire, Golhar and Waller, 1996; Black and Porter, 1996). Researchers later focused on analysing the TQM value as regards improving manufacturing firms' performance, suggesting that its implementation is positively associated with a firm's operational performance in terms of cost, flexibility and quality (Powell, 1995; Easton and Jarrell, 1998; Samson and Terziovski, 1999; Taylor and Wright 2003). Many studies aim to empirically investigate the relationship between the TQM elements and the organisation's performance. Among these TQM elements we can include process management, strategic planning, leadership, people management, customer focus, and information and analysis (Abdullah, 2010; Idris, 2011).

Sufficient proof exists for it to be stated that the implementation of the TQM best practiceshas proved effective and helped to achieve results, such as improved customer satisfaction, increased productivity, a better company image, improved competitiveness and increased profitability (Santos and Álvarez, 2007; Corredor and Goñi, 2010).

The above lines of reasoning will be used as a basis to test the third hypothesis: TQM has a positive significant effect on the performance of the organisation.

Finally, results confirm that HRM practices greatly influence the application of TQM practices and that both practices, when applied simultaneously, also influence quality performance measures (Alfalla et al., 2012; Palo and Padhi, 2005). The improvement in quality results (customer satisfaction, less waste and defective products, employee motivation) leads to an improvement in the company's performance (Jiménez-Jiménez and Martínez-Costa, 2009), in the firm's image (Yang, 2006) or the achievement of competitive advantages (Aragón-Sánchez and Esteban-Lloret, 2010).

That is, some research works confirm the existence of a direct relationship between HPWS and organisational performance. However, we propose that this relationship 
appears as the result of the development of TQM practices which, in this case, work as a mediating variable. For instance, human resource practices such as training or retribution will lead to an improvement in the company's results because they allow and motivate the employees to develop the enterprise's total quality principles and techniques in an effective manner.

Companies should design human resource practices that support comunication, team work, employee empowerment, and quality commitment, through a broadranging rewards system that shows the employees the priority given to quality by the firm's managers. All of these practices will eventually have a significant effect on an organisation's performance (Blackburn and Rosen, 1993).

The above lines of reasoning will be used as a basis to test the fourth hypothesis: TQM acts as a mediating variable in the influence that HPWS have on business performance.

\section{Methodology of analysis}

In this section we present operational measures of the variables used in the study.

The questionnaire employed a five-point scale from 1 (strongly disagree or very unsatisfied) to 5 (strongly agree or very satisfied). That is, the questions reflected the level of agreement with some claims related to the HPWS and the TQM, and the level of satisfaction in relation to the organisational results (see Appendix A for a detailed listing of the items).

\subsection{High-performance work systems (HPWS)}

The HPWS measurement is based on the 12 items developed by Zhang, Di Fan and Zhu (2014). Their research shows a positive and significant relationship between the HPWS and the company's social performance. The elements of HPWS that the authors incorporate into the questionnaire are: recruitment, training, promotion, compensation, employee participation, evaluation, job security, and work design, and it is based on the analysis of Huselid (1995), Delery and Doty (1996), Wright, Gardner and Moynihan (2003), Datta et al. (2005), Xiao and Björkman (2006), and Gong, Chang and Cheung (2010). An EFA showed three distinctive factors (with eigenvalues of above 1) grouping $61.27 \%$ of the variance. As the communalities of one item had a value under 0.3 (less than the recommended threshold of 0.5 ), we previously made the decision to exclude that item from the statistical analysis (HPWS7, see appendix). The subjective items ranged from 1 (strongly disagree) to 5 (strongly agree). 


\subsection{Total quality management (TQM)}

The TQM is based on the 9 items developed by Marín (2013). This research shows a positive and significant relationship between the TQM and the organisational performance and no-financial ratios. The scale is based in the studies developed by Hayes, Wheelwright and Clark (1984), Skinner (1985), Hall (1987), Schonberger (1986), and Chenhall (1997), and considers elements such as customer and supplier management, business coordination, managers' commitment, and a decrease in waste and defective products. We checked the dimensionality of the measureby applying an exploratory factor analysis (EFA) to the scale. We found only one factor (with an eigenvalue of above 1) with an accumulated variance of $61.18 \%$. The subjective items ranged from 1 (strongly disagree) to 5 (strongly agree).

\subsection{Business performance (BP)}

The business performance is based on the 8 items developed by Fuentes and Hurtado (2002). These authors used the Adam (1994), Anderson et al. (1995), Forker, Vickery and Droge (1996), Mohr-Jackson (1998), Grandzol and Gershon (1998) and Easton and Jarrell (1998) scales. Fuentes and Hurtado (2002) focus on firms with a TQM system, using both operative and financial ratios. We found only one factor (with an eigenvalue of above 1), with an accumulated variance of $70.43 \%$. The subjective items ranged from 1 (strongly unsatisfied) to 5 (strongly satisfied).

\section{Empirical data and analysis}

The hypotheses were tested using SEM, which permits a simultaneous test of the causal relationships among multiple variables in a model and provides techniques with which to correct for measurement errors that are potential problems in behavioural research. When carrying out a SEM analysis, it is necessary to choose between two statistical methods (Hair, Ringle and Sarstedt, 2013): the method based on the covariance analysis (MBC) or the method based on variance or components (Partial Least Squares, PLS). We have chosen PLS-SEM analysis because: $1^{\circ}$ the proposed model has an approach to formative constructs (Model B)_(Henseler, 2017; Rigdon, 2016); $2^{\circ}$ it is a complex model in which we consider both direct and mediation relationships; and $3^{\circ}$ we have first-order and second-order constructs (Ali, Rasoolimanesh, Sarstedt, Ringle and Ryu, 2018). We followed the two-steps procedure normally recommended for SEM estimations and first made an adjustment to the measurement models, after which we adjusted the structural models.

We have introduced two control variables into the structural model: the company's age and the company's size (number of employees). We eventually, decided not to consider these variables because they do not show significant effects. 
As three distinct factors were found when we applied an EFA to the HPWS scale, it was subsequently considered to be a multidimensional construct in the SEM-PLS model. This construct thus had a common factor approach (reflective indicators) in its first order and a causal approach (formative indicators) in its second order (the three factors resulting from an EFA application). It was modelled by means of a two-step approach (Wright, Campbell, Thatcher and Roberts, 2012), in which the aggregated scores of the first-order dimensions are first estimated, and these scores are then used to model the second-order construct. Following Mikulić (2018) and, Mikulić and Ryan (2018), the remaining constructs of the structural model (TQM and BP) have been operazionalized like an approach to formatives (Model B), considering the dispersion and correlation measures analysis and the nature of the construct.

\subsection{Population, sample and data collection}

The sample was elaborated using the Spanish SABI data base. Sampling was carried out on companies from a region in Spain (Castilla-La Mancha) with at least 25 employees and belonging to different industrial sectors and services. Inactive companies were excluded, signifying that the whole final sample was made up of 876 firms.

The principal form of data collection was mail, first in October and later in November 2016, and more responses were also obtained by means, in same cases, of personal and telephone interviews.

The questionnaires were sent to the officer/coordinator of the Human Resources Department and Quality Department. Of the 876 questionnaires distributed, 142 were returned. However, some of them were incomplete, signifying that we eventually obtained 129 usable questionnaires, yielding a response rate of 14.7 percent. An analysis of the differences between respondents and non-respondents for a given set of variables tests for non-response bias T-test revealed no significant differences between the two groups in relation to size and age.

We have also tested that BP is significantly correlated with two objective indicators: the Return on Assets (ROA) and Return on Equity (ROE) (the mean values over the last three years) collected from the responding companies' financial reports (SABI database).

\subsection{Measurement model}

The validity of the formative construct approach (HPWS, TQM and BP) was verified by analysing the variance inflation factor $(\mathrm{VIF}<5)$ in order to ensure the non-existence of multi-collinearity (Table 1). All the weights for the formative construct were significant with $\mathrm{p}<0.001$. 
Emilio Ruiz et al. • Do high performance work systems enhance business performance?...

Table 1: Assessment of measurement model

\begin{tabular}{|l|c|c|c|}
\hline \multicolumn{1}{|c|}{ Construct } & Mean & S.D. & Range of VIF \\
\hline HPWS & 3.89 & 1.07 & $1.423-1.567$ \\
\hline TQM & 3.81 & 1.03 & $1.479-2.534$ \\
\hline BP & 3.65 & 0.83 & $1.835-2.181$ \\
\hline
\end{tabular}

Source: Authors' calculations

\subsection{Structural model}

It is first necessary to have a Variance Inflation Factor (VIF) of 5 or lower so as to avoid the collinearity problem (Hair, Hult, Ringle and Sarstedt, 2017). Both values are lower than 5 (1.00 and 2.25).

Path coefficient estimates using bootstrapping were employed to assess significance (Table 2). In this procedure, a large number of subsamples (in this case, 5000, and a sample size of 129) are taken from the original sample with replacement in order to provide bootstrap standard errors, which in turn provide approximate $t$-values for the significance testing of the structural path. As will be noted, all the values related to the direct influence of HPWS in BP are significant $(\beta=0.508, \mathrm{p}<0.001)$, as are the relationships between HPWS and TQM $(\beta=0.701, \mathrm{p}<0.001)$, and TQM and BP $(\beta=0.194, p<0.05)$ (Table 2 and Figure 1$)$.

Figure 1: Structural model results

H.1

$0.508^{* * *}$

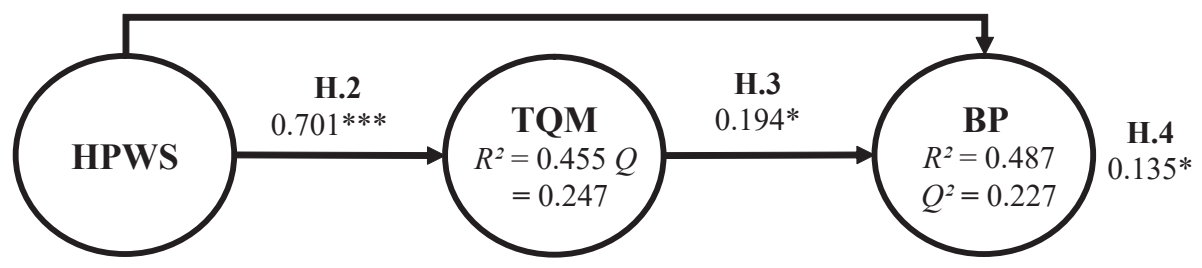

Source: Author's calculations

In order to verify the predictive capacity of the model, we calculated the determination coeficcient $\left(\mathrm{R}^{2}\right)$ which, when following the procedure suggested by Falk and Miller (1992), should not be lower than 0.1. Geisser (1974) and Stone (1974) also recommend the Stone-Geisser $\left(\mathrm{Q}^{2}\right)$ test through the use of the Blindfolding procedure. Chin (1998) claims that $\mathrm{Q}^{2}$ should be higher than 0 in order to have relevants constructs (Figure 1). 


\subsubsection{Mediation analysis}

Finally, we verified whether TQM acts as a mediating variable in the influence that HPWS have on business performance (Hypothesis 3). This procedure evaluates the significance of the direct and indirect effects and the Variance Accounted For (VAF).

Table 2: Structural analysis: direct and mediating effects

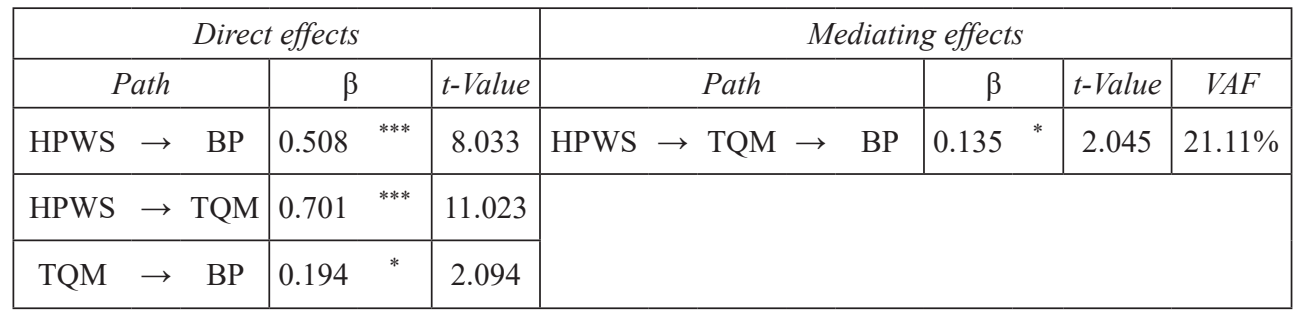

Note: $\mathrm{t}(0.05 ; 4999)=1.645^{*} ; \mathrm{t}(0.01 ; 4999)=2,327^{* *} ; \mathrm{t}(0.001 ; 4999)=3,092^{* * *} ;($ based on $\mathrm{t}(4999)$, one-tailed test).

Source: Authors' calculations

The direct effect between HPWS and BP is significant $(\beta=0.508, \mathrm{p}<0.001)$, as we have seen previously, and we therefore went on to verify whether the indirect effect was also significant $(\beta=0.135, \mathrm{p}<0.05)$. The VAF makes it possible to discover which part of the total effect of the independent variable on the dependent variable is explained by the mediation. A VAF lower than $20 \%$ indicates no mediation, between $20 \%$ and $80 \%$ indicates a partial mediation, and higher than $80 \%$ indicates full mediation. A partially mediated relationship exists in our model if we consider the $21.11 \%$ VAF value (Table 2).

\section{Results and discussion}

Our first hypothesis sets out a direct relationship between HPWS and business performance. Given that this influence is statistically significant, the hypothesis can be confirmed and a positive influence of the introduction of HPWS on the company results can be affirmed.

The results also demonstrate that HPWS is positively and significantly associated with TQM (hypothesis 2). That is, human resource practices, such as recruiting and selection, training, employee participation, employee performance evaluation and incentive compensations, appear to have an influence on TQM. The implementation of these types of human resource practices results in quality certifications (ISO, EFQM), product quality improvement, customer satisfaction or awards which improve the company's image. 
The third hypothesis sets out a direct relationship between TQM and business performance. A positive and significant influence of the introduction of TQM on the company results can be affirmed. The implementation of TQM practices not only has an impact on customer satisfaction and the company's image but also implies an improvement to competitiveness and profitability.

The fourth hypothesis posits the mediational effect of TQM on the relationship between HPWS and business performance. This is a partial mediation, with a VAF of $21.11 \%$. That is, we have confirmed that HPWS have an influence on the business results and do so by means of TQM. The implantation of both variables in the company will have a synergyc effect on business performance.

\section{Conclusions}

This study is related to the configurational approach and the resource-based view of the firm and has extended previous research and provides a better understanding of the association between HPWS/TQM and business performance.

With regard to the practical contributions of this research, given the direct influence of HPWS and TQM on business performance, the top management in the organisation should conduct formal human resource management and total quality management programmes focused on empowerment, reward and recognition, customer, teamwork and organisational communication. Top managers should monitor their formal structures and systems in order to ensure that TQM is truly incorporated into the actual strategic business planning process. It is vital to align HPWS with the requirements of a TQM system and practices. This study provides important guidelines with which to improve performance. The empirical evidence in the shape of association among HPWS, TQM, and organisational performance shows that those companies that provide resources for these practices can make relevant improvements to their business results. A variable such as TQM, which is considered strategic owing to its influence on a company's results, is now increasing in competitive importance because, when integrated with human resource practices, it improves these results much more. These conclusions have eabled us to cover the gap in literature as regards the role of TQM as a key mediating variable.

The authors realise that there are some limitations in this study that need to be acknowledged and addressed by future research. First, the data was collected using a questionnaire technique and the information obtained might not, therefore, be reliable, signifying that the research findings could be biased. We have, at least partially, attempted to overcome this limitation by addressing the questionnaires to the top managers and, in some cases, carrying out personal interviews. Second, a cross-sectional data analysis cannot confirm the direction of causality implied in our research model and it is, therefore, necessary to be cautious as regards our 
conclusions concerning causality. It is for this reason that a longitudinal study is strongly recommended. Finally, the study examines different sectors, but we have not included this variable in the model. This aspect could also be considered in future research, in addition to data from other regions or countries.

\section{References}

Abdullah, A. (2010) "Measuring TQM implementation: A case study of Malaysian SMEs", Measuring Business Excellence, Vol. 14, No. 3, pp. 3-15, doi: 10.1108/ 13683041011074173.

Abu-Doleh, J. (2012) "Human resource management and total quality management linkage-rhetoric and reality: Evidence from an empirical study", International Journal of Commerce and Management, Vol. 22, No. 3, pp. 219-234, doi: 10.1108/10569211211260300.

Adam, E. (1994) "Alternative quality improvement practices and organization performance", Journal of Operations Management, Vol. 12, No. 1, pp. 27-44, doi: 10.1016/0272-6963(94)90004-3.

Ahire, S., Golhar, D., Waller, M. (1996) "Development and validation of TQM implementation constructs", Decision Sciences, Vol. 27, No. 1, pp. 23-56, doi: 10.1111/j.1540-5915.1996.tb00842.x.

Alfalla, R., Marín, J., Medina, C. (2012) "Is worker commitment necessary for achieving competitive advantage and customer satisfaction when companies use HRM and TQM practices?”, Universia Business Review, Vol. 36, pp. 64-88.

Anderson, M., Sohal, A. M. (1999) "A study of the relationship between quality management practices and performance in small businesses". International Journal of Quality \& Reliability Management, Vol. 16, No. 9, pp. 859-877, doi: 10.1108/02656719910289168.

Appelbaum, E., Bailey, T., Berg, P., Kalleberg, A. (2000) "Manufacturing advantage: Why high-performance work systems pay off". Washington, DC: Economic Policy Institute.

Aquilani, B., Silvestri, C., Ruggieri, A., Gatti, C. (2017) "A systematic literature review on total quality management critical success factors and the identification of new avenues of research". The TQM Journal, Vol. 29, No. 1, pp. 184-213, doi: 10.1108/tqm-01-2016-0003.

Aragón-Sánchez, S., Esteban-Lloret, N. (2010) “Training in the Spanish company: Just improving firm performance?", Universia Business Review, Vol. 26, pp. 34-57.

Batt, R. (2002) "Managing customer services: Human resource practices, quit rates, and sales growth", Academy of Management Journal, Vol. 45, No. 3, pp. 587597, doi: $10.2307 / 3069383$. 
Black, S., Porter, L. (1996) "Identification of the critical factors of TQM", Decision Sciences, Vol. 27, No 1, pp. 1-21, doi: 10.1111/j.1540-5915.1996.tb00841.x.

Blackburn, R., Rosen, B. (1993) "Total quality and human resource management: Lessons learned from Baldbridge Award-winning companies", Academy of Management Executive, Vol. 7, No. 3, pp. 49-66, doi: 10.5465/ame.1993. 9411302347.

Boon, O.K., Arumugam, V., Samaun S., Abu N. (2007) "HRM and TQM: association with job involvement", Personnel Review, Vol. 36, No. 6, pp. 939 962, doi: 10.1108/00483480710822445.

Bouranta, N., Psomas, E. L., Pantouvakis, A. (2017) "Identifying the critical determinants of TQM and their impact on company performance: Evidence from the hotel industry of Greece", The TQM Journal, Vol. 29, No 1, pp. 147166, doi: 10.1108/tqm-11-2015-0142.

Chenhall, R. H. (1997) "Reliance on manufacturing performance measures, total quality management and organizational performance", Management Accounting Research, Vol. 8, No. 2, pp. 187-206, doi: 10.1006/mare.1996.0038.

Chin, W. (1998) "Issues and Opinion on Structural Equation Modeling", MIS Quarterly, Vol. 22, No. 1, pp. 7-16.

Corredor, P., Goñi S. (2010) "Tipos de premios a la calidad y efectos sobre la rentabilidad de la empresa", Spanish Journal of Finance and Accounting/ Revista Española de Financiación and Contabilidad, Vol. 39, No. 148, pp. 637-654, doi: 10.1080/02102412.2010.10779692.

Datta, D., Guthrie, J., Wright, P. (2005) "Human resource management and labour productivity: Does industry matter?" Academy of Management Journal, Vol. 48, No. 1, pp. 135-146, doi: 10.5465/amj.2005.15993158.

Delaney, J., Huselid, M. (1996) "The impact of human resources management practices on perceptions of organizational performance", Academy of Management Journal, Vol. 39, No. 4, pp. 949-969, doi: 10.2307/256718.

Delery, J., Doty, D. (1996) "Modes of theorizing in strategic human resource management: Tests of universalistic, contingency, and configurational performance predictions", Academy of Management Journal, Vol. 39, No. 4, pp. 802-835, doi: $10.5465 / 256713$.

Doty, D.H., Glick, W.H. (1994) "Typologies as a unique form of theory building: toward improved understanding and modeling", Academy of Management Review, Vol. 19, No. 2, pp. 230-251, doi: 10.5465/amr.1994.9410210748.

Easton, G., Jarrell, S. (1998) "The effects of total quality management on corporate performance: An empirical investigation", Journal of Business, Vol. 71, No. 2, pp. 253-307, doi: 10.1086/209744.

Escrig, A. B., Bou, J. C., Roca, V. (2001) Measuring the relationship between total quality management and sustainable competitive advantage: A resource-based 
view. Total quality management, Vol. 12, No. 7-8, pp. 932-938, doi: 10.1080/ 09544120100000018.

Evans, J. (1992) A report of the total quality leadership steering committee and working councils, Procter \& Gamble, Milwaukee.

Faizan, A., Rasoolimanesh, S.M., Sarstedt, M., Ringle, C.M, Ryu, K. (2018) “An assessment of the use of partial least squares structural equation modeling (PLS-SEM) in hospitality research", International Journal of Contemporary Hospitality Management, Vol. 30 Issue: 1, pp. 514-538, doi: 10.1108/IJCHM10-2016-0568.

Falk, R. and Miller, N. (1992) A Primer for Soft Modeling, The University of Akron Press, Akron.

Forker, L., Vickery, S., Droge, C. (1996) "The contribution of quality to business performance". International Journal of Operations \& Production Management, Vol. 16, No. 8, pp. 44-62, doi: 10.1108/01443579610125778.

Fornell, C., Larcker, D. (1981) "Evaluating structual equations models with unobservable variables and measurement error". Journal of Marketing Research, Vol. 18, No. 1, pp. 39-50, doi: 10.1177/002224378101800104.

Fuentes, M., Hurtado, N. (2002) "Variables críticas en la medición del desempeño en empresas con implantación de la gestión de la calidad total", Investigaciones Europeas de Dirección y Economía de la Empresa, Vol. 8, No. 2, pp. 87-102.

Geisser, S. (1974) "A predictive approach to the random effects model”, Biometrika, Vol. 61, pp. 101-107, doi: 10.2307/2334290.

Gong, Y., Chang, S., Cheung, S. (2010) "High performance work system and collective OCB: A collective social Exchange perspective", Human Resource Management Journal, Vol. 20, No. 2, pp. 119-137, doi: 10.1111/j.1748-8583.2010.00123.x.

Grandzol, J., Gershon, M. (1998) "A survey instrument for standardizing TQM modeling research". International Journal of Quality Science, Vol. 3, No. 1, pp. 80-105, doi: 10.1108/13598539810203887.

Grant, R.M. (1996) "Towards a knowledge-based theory of the firm", Strategic Management Journal, Vol. 17, pp. 109-122, doi: 10.1002/smj.4250171110.

Guest, D. (1997) "Human resource management and performance: A review and research agenda". International Journal of Human Resource Management, Vol. 8, No. 3, pp. 263-276, doi: 10.1080/095851997341630.

Guthrie, J. (2001) "High involvement work practices, turnover and productivity: Evidence from New Zealand", Academy of Management Journal, Vol. 44, No. 1, pp. 180-192, doi: 10.2307/3069345.

Guthrie, J., Flood, P., Liu, W., Mac Curtain, S. (2009) "High performance work systems in Ireland: Human resource and organizational outcomes", The International Journal of Human Resource Management, Vol. 20, No. 1, pp. 112-125, doi: 10.1080/09585190802528433. 
Hair, J. F. J., Hult, G. T. M., Ringle, C., Sarstedt, M. (2017) “A Primer on Partial Least Squares Structural Equation Modeling (PLS-SEM)" (2nd edition). Thousand Oaks,CA: SAGE Publications.

Hair, J., Ringle, C., Sarstedt, M. (2013) "Partial least squares structural equation modeling: Rigorous applications, better results and higher acceptance", Long Range Planning, Vol. 46, No. 1-2, pp. 1-12, doi: 10.1016/j.lrp.2013.01.001.

Hall, R. (1987) Attaining manufacturing excellence, Irwin: Homewood, Illinois.

Handfield, R., Ghosh, S., Fawcett, S. (1998) "Quality-driven change and its effects on financial performance", Quality Management Journal, Vol. 4, No. 4, pp. 1330, doi: 10.1080/10686967.1997.11918813.

Hayes, R., Wheelwright, S., Clark, K. (1984) "Restoring our competitive edge: Competing through manufacturing", Wiley and Sons, New York.

Henseler, J. (2017) "Bridging design and behavioral research with variance-based structural equation modeling", Journal of Advertising, Vol. 46 No. 1, pp. 178192., doi: 10.1080/00913367.2017.1281780.

Huselid, M. A. (1995) "The impact of human-resource management-practices on turnover, productivity, and corporate financial performance", Academy of management Journal, Vol. 38, No. 3, pp. 635-672, doi: 10.2307/256741.

Huselid, M. A., Jackson, S.E., Schuler, R.S. (1997) “Technical and strategic human resource management effectiveness as determinants of organisation performance", Academy of Management Journal, Vol. 40, No. 1, pp. 171-188, doi: $10.2307 / 257025$.

Ichniowski, C., Shaw, K., Prennushi, G. (1997) "The effects of human resource management practices on productivity: A study of steel finishing lines", The American Economic Review, pp. 291-313.

Idris, F. (2011) "Total quality management (TQM) and sustainable company performances: Examining the relationship in Malaysian firms", International Journal of Business and Society, Vol. 12, No. 1, pp. 31-52.

Izvercian, M., Radu, A., Ivascu, L., Ardelean, B. (2014) "The impact of human resources and total quality management on the enterprise", Procedia-Social and Behavioral Sciences, Vol. 124, pp. 27-33, doi: 10.1016/j.sbspro.2014.02.456.

Jiménez-Jiménez, D., Martínez-Costa, M. (2009) “The performance effect of HRM and TQM: A study in Spanish organizations", International Journal of Operations \& Production Management, Vol. 29, No. 12, pp. 1266-1289, doi: 10.1108/01443570911005992.

Juran, J., and Godfrey, B. (2001) Manual de calidad, McGraw-Hill, España.

Juran, J.M. (1951) Quality control handbook, McGraw-Hill, Nueva York.

Kochan, T., Gittell, J., Lautsch, B. (1995) "Total quality management and human resource systems: An international comparison", The International Journal of Human Resource Management, Vol. 6, No. 2, pp. 201-22, doi: 10.1080/ 09585199500000017. 
Larson, P., Sinha, A. (1995) "The TQM impact: A study of quality manager's perceptions", Quality Management Journal, Vol. 2, No. 3, pp. 53-66, doi: 10.1080/10686967.1995.11918691.

Lee, C. Y., Lee, H. H. (2015) "The integrated relationship among organizational learning, TQM and firm's business performance: A structural equation modeling approach", International Business Research, Vol. 8 No. 5, pp. 43-54, doi: 10.5539/ibr.v8n5p43.

Lemak, D. J., Reed, R. (1997) “Commitment to total quality management: Is there a relationship with firm performance?", Journal of Quality Management, Vol. 2, No. 1, pp. 67-87, doi: 10.1016/s1084-8568(97)90022-5.

Lin, C. (1998) "Success factors of small (and medium) sized enterprise in Taiwan: An analysis of cases", Journal of Small Business Management, Vol. 36, No. 4, pp. $43-56$.

Marín, L. (2013) "Gestión de la Calidad Total e indicadores no financieros: Reflejo del valor de la certificación ISO 9001: 2000", Revista Europea de Dirección and Economía de la Empresa, Vol. 22, No. 2, pp. 97-106, doi: 10.1016/j.redee. 2012.11.002.

Mikulić, J. (2018). Towards an end of measurement misspecification in tourism research: Grammar of theoretical constructs, focus of thought and mind traps. Tourism Management, Vol. 68, pp. 444-449, doi: 10.1016/j.tourman.2018. 04.010 .

Mikulić, J., Ryan, C. (2018). Reflective versus formative confusion in SEM based tourism research: A critical comment. Tourism Management, Vol. 68, pp. 465469, doi: 10.1016/j.tourman.2018.05.002.

Miles, R.E., Snow, C.C. (1984) "Designing Strategic Human Resource Systems, Organizational Dynamics", Vol. 31, No. 1, pp. 36-52, doi: 10.1016/0090-2616 (84)90030-5.

Mohr-Jackson, I. (1998) “Conceptualizing total quality orientation”, European Journal of Marketing, Vol. 32, No. 1-2, pp. 13-22, doi: 10.1108/03090569810197390.

Palo, S., Padhi, N. (2005) "How HR professionals drive TQM: A case study in an Indian organization", The TQM Magazine, Vol. 17, No. 5, pp. 467-85, doi: 10.1108/09544780510615960.

Peña, I.; Sánchez de Pablo, J.D.; Hernández, F., Villasalero, M. (2015) “Linking highperformance work systems and business performance: the role of employees' attitudes and behaviours", European Journal of International Management, Vol. 9, No. 5, pp. 648-666, doi: 10.1504/ejim.2015.071549.

Pfeffer, J. (1994) "Competitive advantage trough people", California Management Review, Vol. 36, No. 2, pp. 9-28, doi: 10.2307/41165742.

Pfeffer, J. (1998) "Seven practices of successful organizations", California Management Review, Vol. 40, No. 2, pp. 96-124, doi: 10.2307/41165742. 
Powell, T. (1995) "Total quality management as competitive advantage: A review and empirical study", Strategic Management Journal, Vol. 16, No. 1, pp. 15-37, doi: $10.1002 / \mathrm{smj} .4250160105$.

Riaz, S. (2016) "High Performance Work Systems and Organizational Performance: An Empirical Study on Manufacturing and Service Organizations in Pakistan", Public Organization Review, Vol. 16, No. 4, pp. 421-442, doi: 10.1007/s11115015-0315-1.

Rigdon, E.E. (2016) "Choosing PLS path modeling as analytical method in European management research: a realist perspective", European Management Journal, Vol. 34, No. 6, pp. 598-605.

Samson, D., Terziovski, M. (1999) "The relationship between total quality management practices and operational performance" Journal of operations management, Vol. 17, No. 4, pp. 393-409, doi: 10.1016/s0272-6963(98)00046-1.

Santos, M., Álvarez, L. (2007) "Gestión de la calidad total de acuerdos con el modelo EFQM: Evidencias sobre sus efectivos en el rendimiento empresarial", Universia Business Review, Vol. 13, pp. 76-89.

Schonberger, J. (1986): World-class manufacturing: The lessons of simplicity applied, The Free Press, New York.

Schuler, R.S., Jackson, S.E. (1987) "Linking competitive strategy with human resource practices", Academy of Management Executive, Vol. 1, No. 3, pp. $207-$ 219, doi: 10.5465/ame.1987.4275740.

Skinner, W. (1985): Manufacturing: the formidable competitive weapon, Wiley, New York.

Soltani, E., Gennard, J., Van der Meer, R., Williams, T. (2004) "HR performance evaluation in the context of TQM: A review of the literature", International Journal of Quality \& Reliability Management, Vol. 21, No. 4, pp. 377-396, doi: 10.1108/02656710410530082.

Stone, M. (1974) "Cross-validatory choice and assessment of statistical predictions", Journal of the Royal Statistical Society, Vol. 36, No. 2, pp. 111147, doi: 10.1111/j.2517-6161.1974.tb00994.x.

Takeuchi, R., Chen, G., Lepak, D. (2009) "Through the looking glass of a social system: Cross level effects of high-performance work systems on employees'attitudes", Personnel Psychology, Vol. 62, No. 1, pp. 1-29, doi: 10.1111/j.1744-6570.2008.01127.x.

Takeuchi, R., Lepak, D., Wang, H., Takeuchi, K. (2007) “An empirical examination of the mechanisms mediating between high-performance work systems and the performance of Japanese organizations", Journal of Applied Psychology, Vol. 92, No. 4, pp. 1069-1083, doi: 10.1037/0021-9010.92.4.1069.

Taylor, W., Wright, G. (2003) "A longitudinal study of TQM implementation: Factors influencing success and failure", Omega, Vol. 31, No. 2, pp. 97-111, doi: 10.1016/s0305-0483(03)00017-3. 
Valmohammadi, C., Roshanzamir, S. (2015) "The guidelines of improvement: Relations among organizational culture, TQM and performance", International Journal of Production Economics, Vol. 164, pp. 167-178, doi: 10.1016/j. ijpe.2014.12.028.

Vintern, G. (2000) "Training in small-and medium-sized enterprises", Industrial and Commercial Training, Vol. 32, No. 1, pp. 9-14, doi: 10.1108/00197850010311112.

Vouzas, F. (2007) "Investigating the human resources context and content on TQM, business excellence and ISO 9001:2000”, Measuring Business Excellence, Vol. 11, No. 3, pp. 21-29, doi: 10.1108/13683040710820728.

Warren, L., Hutchinson, W. (2000) "Success factors for high technology SMEs: A case Study from Australia", Journal of Small Business Management, Vol. 38, No. 3, pp. 86-91.

Wood, S. (1999) "Human resource management and performance, International journal of management reviews, Vol. 1, No. 4, pp. 367-413, doi: 10.1111/14682370.00020 .

Wright, P., Gardner, T., Moynihan, L. (2003) "The impact of HR practices on the performance of business units", Human Resource Management Journal, Vol. 13, No. 3, pp. 21-36, doi: 10.1111/j.1748-8583.2003.tb00096.x.

Wright, P.M., Snell, S.A. (1991) "Toward and integrative view of strategic human resource management”, Human Resource Management Review, Vol. 1, No. 3, pp. 203-205, doi: 10.1016/1053-4822(91)90015-5.

Wright, R. T., Campbell, D. E., Thatcher, J. B., Roberts, N. (2012) “Operationalizing multidimensional constructs in structural equation modeling: Recommendations for IS research", Communications of the Association for Information Systems, Vol. 30, No. 1, pp. 367-412, doi: 10.17705/1cais.03023.

Wruck, K. H., Jensen, M. C. (1998) "The two key principles behind efectivetqm programs", European Financial Management, Vol. 4, No. 3, pp. 401-423, doi: 10.1111/1468-036x.00073.

Xiao, Z., Björkman, I. (2006) "High commitment work systems in Chinese organizations: A preliminary measure", Management and Organization Review, Vol. 2, No. 3, pp. 403-422, doi: 10.1111/j.1740-8784.2006.00049.x.

Yang, C.C. (2005) "An integrated model of TQ and GE-Six Sigma", International Journal of Six Sigma and competitive advantage”, Vol. 1, No. 1, pp. 97-105, doi: 10.1504/ijssca.2004.005280.

Yang, C.C.(2006) "The impact of human resource management practices on the implementation of total quality management: An empirical study on high-tech firms", The TQM Magazine, Vol. 18, No. 2, pp. 162-173, doi: 10.1108/ 09544780610647874.

Zhang, B., Morris, J. (2014) "High-performance work systems and organizational performance: Testing the mediation role of employee outcomes using evidence 
from PR China", The International Journal of Human Resource Management, Vol. 25, No. 1, pp. 68-90, doi: 10.1080/09585192.2013.781524.

Zhang, M., Di Fan, D., Zhu, C. (2014) "High-performance work systems, corporate social performance and employee outcomes: exploring the missing links", Journal of business ethics, Vol. 120, No. 3, pp. 423-435, doi: 10.1007/s10551013-1672-8.

Zhang, M., Zhu, C., Dowling, P., Bartram, T. (2013) "Exploring the effects of highperformance work systems (HPWS) on the work-related well-being of Chinese hospital employees", The International Journal of Human Resource Management, Vol. 24, No. 16, pp. 3196-3212, doi: 10.1080/09585192.2013.775026. 
Emilio Ruiz et al. • Do high performance work systems enhance business performance?...

\title{
Mogu li visokoučinkoviti sustavi rada povećati uspješnost poslovanja? Ispitivanje posrednog utjecaja cjelokupnog upravljanja kvalitetom
}

\author{
Emilio Ruiz ${ }^{1}$, Jesús David Sánchez de Pablo ${ }^{2}$, Rosa M. Muñoz ${ }^{3}$, Isidro Peña ${ }^{4}$
}

\begin{abstract}
Sažetak
Ovaj rad analizira utjecaj visokoučinkovitih sustava rada (HPWS) i cjelovitog upravljanja kvalitetom (TQM) na poslovne rezultate. Opsežni pregled literature omogućio je postavljanje četiri hipoteze uz model složene regresijske analize odnosa koji su testirani pomoću modeliranja strukturnih jednadžbi (SEM) primjenom tehnike parcijalnih najmanjih kvadrata (PLS). Rezultati pokazuju da HPWS pozitivno utječe na uspješnost poslovanja kao i TQM, koji za uzvrat izravno poboljšava poslovne rezultate i utječe na odnos HPWS-a i poslovne uspješnosti. Iz toga proizlazi da je za poduzeće ključna strategija integracija upravljanja ljudskim resursima i cjelokupnog upravljanja kvalitetom.
\end{abstract}

Ključne riječi: visokoučinkoviti sustavi rada, cjelovito upravljanje kvalitetom, posredovanje, poslovna uspješnost, metoda parcijalnih najmanjih kvadrata

JEL klasifikacija: M50

${ }_{1}$ Doktorand, University of Castilla-La Mancha, Faculty of Law of Social Sciences, Ronda de Toledo s/n, 13071 Ciudad Real, Španjolska. Znanstveni interes: strateško upravljanje ljudskim resursima, cjelokupno upravljanje kvalitetom i parcijalna projekcija najmanjih kvadrata. Tel.: +34926295300.Fax:+34 926295407.E-mail:emilio.ruiz@alu.uclm.es.

2 Docent, University of Castilla-La Mancha, Faculty of Law of Social Sciences, Ronda de Toledo s/n, 13071 Ciudad Real, Španjolska. Znanstveni interes: strateško udruživanje, inovacije, upravljanje znanjem i strateško upravljanje ljudskim resursima. Tel.: +34 926295300 Ext. 3429. Fax: +34 926295407.E-mail: jesusdavid.sanchez@uclm.es (osoba za kontakt).

3 Redoviti profesor, University of Castilla-La Mancha, Faculty of Law of Social Sciences, Ronda de Toledo s/n, 13071 Ciudad Real, Španjolska. Znanstveni interes: strateško upravljanje ljudskim resursima, poduzetništvo i društvena odgovornost poduzeća. Phone: +34926295300 Ext.3594.Fax:+34 926295407.E-mail: rosamaria.munoz@uclm.es.

4 Docent, University of Castilla-La Mancha, Faculty of Law of Social Sciences, Ronda de Toledo s/n, 13071 Ciudad Real, Španjolska. Znanstveni interes: strateško udruživanje, inovacije, upravljanje znanjem i strateško upravljanje ljudskim resursima. Tel.: +34926295300 Ext. 3531. Fax: +34 926295407. E-mail: isidro.pena@uclm.es. 


\section{Appendix (questionnaire items)}

High-performance work systems (HPWS). Over the last three years, in the company (from 1-strongly disagree to 5-strongly agree):

- HPWS1: Applicants undergo structured interviews before being hired.

- HPWS2: Our company provides employees with training assistance, thus enabling them to upgrade their qualifications.

- HPWS3: Employees have clear career paths within the company.

- HPWS4: Qualified employees have the opportunity to be promoted to positions of greater pay and/or responsibility within the company.

- HPWS5: Performance assessments are conducted regularly.

- HPWS6: The outcome of performance assessment is used for bonuses and promotion.

- HPWS7: There is an agreement that if the company deals with financial problems, dismissing employees would be the last choice for the firm.

- HPWS8: Employees are encouraged to take job-related decisions.

- HPWS9: Supervisors often ask employees to participate in decisions.

- HPWS10: Supervisors keep open communications with employees.

- HPWS11: Current job duties are shaped more by the employee than by a specific job description.

- HPWS12: Employees have the opportunity to earn bonuses for productivity, performance or other individual performance outcomes.

Total quality management (TQM). Over the last three years (from 1-strongly disagree to 5-strongly agree):

- TQM1: There has been highly coordinated work between the company's functional areas, departments, subunits or business units.

- TQM2: The continuous identification of customers' needs and preferences is very important for the firm.

- TQM3: Company personnel participate in the formulation of the quality strategic plan.

- TQM4: Company employees participate in the elaboration and implementation of quality improvement programmes. 
- TQM5: There are quality programmes in the company that are oriented towards improving the duration of production cycles.

- TQM6: There are quality practices in the company that are oriented towards reducing activities that do not add value to productive processes.

- TQM7: The Company has developed procedures in order to control and reduce the number of defective products.

- TQM8: Suppliers are usually involved in the company's quality programmes.

- TQM9: The top management team is strongly committed to total quality in every aspect and ambit of the company.

Business performance (BP). Over the last three years (from 1-strongly unsatisfied to 5-strongly satisfied):

- BP1: Benefits have increased.

- BP2: Return on assets has increased.

- BP3: Sales have increased.

- BP4: Market share has increased.

- BP5: Customers' complaints have decreased.

- BP6: Customers' satisfaction has increased.

- BP7: The level of defective products or services has decreased.

- BP8: The customer's demanded quality level has been achieved. 